VOLCANIC ACTION IN THE BRITISH ISLES.

$\mathrm{A}^{\mathrm{T}}$ the anniversary of the Geological Society, held on the Igth inst., the retiring President, Sir Archibald Geikie, gave the annual address, which was devoted to a continuation of the subject treated of by him last year. He now dealt with the history of volcanic action in this country from the close of the Silurian period up to older Tertiary time. The remarkable volcanic outbursts that took place in the great lakes of the Lower Old Red Sandstone were first described. From different vents over central Scotland, piles of lava and tuff, much thicker than the height of Vesuvius, were accumulated, and their remains now form the most conspicuous hill-ranges of that district. It was shown how the subterranean activity gradually lessened and died out, with only a slight revival in the far north during the time of the Upper Old Red Sandstone, and how it broke out again with great vigour at the beginning of the Carboniferous period. Sir Archibald pointed out that the Carboniferous volcanoes belonged to two distinct types and two separate epochs of eruption. The earlier series produced extensive submarine lavasheets, the remains of which now rise as broad terraced plateaux over parts of the lowlands of Scotland. The later series manifested itself chiefly in the formation of numerous cones of ashes, like the puys of Auvergne, which were dotted over the lagoons and shallow seas in central Scotland, Derbyshire, Devonshire, and the southwest of Ireland. After a long quiescence, volcanic action once more reappeared in the Permian period; and numerous small vents were opened in Fife and Ayrshire, and far to the south in Devonshire. With these eruptions the long record of Palæozoic volcanic activity closed. No trace has yet been discovered of any volcanic rocks intercalated among the Secondary formations of this country, so that the whole of the vast interval of the Mesozoic period was a prolonged time of quiescence. At last, when the soft clays and sands of the Lower Tertiary deposits of the south-east of England began to be laid down, a stupendous series of fissures was opened across the greater part of Scotland, the north of England, and the north of Ireland. Into these fissures lava rose, forming a notable system of parallel dykes. Along the great hollow from Antrim northwards between the outer Hebrides and the mainland of Scotland, the lava flowed out at the surface and formed the well-known basaltic plateaux of that region.

The address concluded with a summary of the more important facts in British volcanic history bearing on the investigation of the nature of volcanic action. Among these Sir Archibald laid special stress on the evidence for volcanic periods, during each of which there was a gradual change of the internal magma from a basic to an acid condition, and he pointed out how this cycle had been repeated again and again even within the same limited area of eruption. In conclusion, he dweit on the segregation of minerals in large eruptive masses, and indicated the importance of this fact in the investigation, not only of the constitution and changes of the volcanic magma, but also of the ancient gneisses where what appear to be original structures have not yet been effaced.

\section{THE CENTENARY OF MURCHISON.} $\mathrm{O}^{\mathrm{N}}$ February 19, 1792, Roderick Impey Murchison curious and appropriate coincidence, the anniversary of the Geological Society, the date of which is fixed by statute, fell this year on the Igth of the present month, the hundredth anniversary of the birth of the illustrious author of the "Silurian System." It was a further remarkable conjuncture that the President of the Society, who had to give the annual address, and take notice of the centenary, was Murchison's literary executor, who was designated by him as the first Professor of Geology in the chair which he founded in the University of Edinburgh, and who now fills the office which he held for so many years-that of Director-General of the Geological Survey. In referring to the doubly interesting features of this anniversary, Sir Archibald Geikie spoke of his great chief with warm admiration. The twenty years which have passed since Murchison's death enable geologists to make a truer estimate of Murchison's real achievements than was possible at the time when his commanding presence filled so prominent a place in the scientific world of his day. They have been able to correct some of his observations and discard some of his generalizations, yet the solid mass of original work done by him remains as a lasting memorial of his genius and industry. In the broad basis of facts, and in the skilful marshalling of these facts in their ordered relations, which distinguished his work among the Silurian rocks, the hand of a consummate master of geological investigation is to be traced. His name has become a household word in geology, and will go down to future ages as that of one of the great pioneers of the science.

Murchison, during all his scientific career, was closely associated with the Geological Society, and took a keen personal interest in its welfare. By his will he left a sum of money to found a medal and fund to be given annually for the reward and encouragement of geological research. This year the medal was awarded to Prof. A. $\mathrm{H}$. Green, of Oxford, and the balance of the fund to Mr. Beeby Thomson. An interesting proof of the affectionate regard entertained for Murchison's memory was afforded by an announcement made by the President. He stated that, a few days before the meeting, an old friend of Murchison, who desired to remain unknown, had come to him and asked to be allowed to offer a slight tribute in remembrance of the man and his work, on his centenary, at the anniversary meeting of the Society. The President was requested to select two geologists (by preference Scotsmen) who were carrying on geological work in Murchison's spirit, and seeking to advance the special branches of research to which he devoted himself, and to present to each of them a cheque for $£ 50$, with a framed portrait of the author of the "Silurian System." Sir Archibald Geikie said that the task assigned to him was made comparatively easy by the terms of the generous gift. He had no doubt that the Society would agree with him that there were pre-eminently two Scottish geologists marked out as recipients of this benefaction, who were disciples of Murchison, and were carrying on his work, but with no slavish obedience to the opinions of their master, and who, by their conjoint work, alike with hammer and pen, well deserved this unexpected and appropriate reward-Mr. B. N. Peach and Mr. John Horne. As a touching addition to this pleasing incident, we have since learnt that while the anniversary was being held at Burlington House, the faithful friend who had made this offering to Murchison's memory was engaged in the cemetery at Brompton carefully brushing and washing his tomb. Driving snow was falling at the time from a gloomy sky, in strange contrast with the glow of affection that was piously renovating the inscription that records the name and resting-place of one of the great leaders of modern geology.

\section{H. W. BATES, THE NATURALIST OF THE AMAZONS.}

H ENRY WALTER BATES was a native of Leicester, and was engaged in his father's warehouse when, about the year I 845 , he made the acquaintance of Alfred Russel Wallace, then English master in the Collegiate

NO. I 165 , VOL. 45] 